\title{
Influence of C14 Alkane Stress on Antioxidant Defense Capacity, Mineral Nutrient Elements Accumulation and Cadmium Uptake of Ryegrass
}

\section{Lizhu Yuan}

Shandong Provincial Key Laboratory of Applied Microbiology/National-Local Joint Engineering Laboratory of Contaminated Soil Remediation by Bio-physicochemical Synergistic Process

\section{Penghong Guo}

Arizona State University

Shuhai Guo ( $\nabla$ shuhaiguo@iae.ac.cn )

Shandong Provincial Key Laboratory of Applied Microbiology/National-Local Joint Engineering Laboratory of Contaminated Soil Remediation by Bio-physicochemical Synergistic Process

\section{Jianing Wang}

Shandong Provincial Key Laboratory of Applied Microbiology

\section{Yujie Huang}

Shandong Provincial Key Laboratory of Applied Microbiology

\section{Research Article}

Keywords: C14 alkane, Cd uptake, Antioxidant enzymes, Mineral nutrient elements

Posted Date: May 28th, 2021

DOl: https://doi.org/10.21203/rs.3.rs-490783/v1

License: (c) (i) This work is licensed under a Creative Commons Attribution 4.0 International License. Read Full License

Version of Record: A version of this preprint was published at Environmental Science and Pollution Research on October 1st, 2021. See the published version at https://doi.org/10.1007/s11356-021-16806$\mathrm{x}$. 


\section{Abstract}

In order to explore the influence of C14 alkane on physiological stress responses, mineral nutrient elements uptake, cadmium (Cd) transfer and uptake characteristics of Lolium perenne L. (ryegrass), a series of pot trials were conducted which included a moderate level of $\mathrm{Cd}\left(2.182 \mathrm{mg} \cdot \mathrm{kg}^{-1}\right)$ without (control) and with five levels of $\mathrm{C} 14$ alkane $(\mathrm{V} / \mathrm{m}, 0.1 \%, 0.2 \%, 0.5 \%, 1 \%, 2 \%)$. Biomass and Cd content in the root and shoot, chlorophyll content, antioxidant enzymes activity, mineral nutrient elements in the shoot of ryegrass were determined at the end of the experiment. The results indicated that $\mathrm{Cd}$ uptake significantly elevated at $0.1 \% \mathrm{C} 14$ alkane treatment, then gradually decreased with the increase of $\mathrm{C} 14$ alkane concentration. Compared with the control, chlorophyll content was significantly suppressed and malondialdehyde (MDA) concentration obviously increased. Superoxide dismutase (SOD) activity and catalase (CAT) activity significantly increased to prevent the C14 alkane stress. With the increased of C14 alkane, the $\mathrm{Mn}$ concentration gradually increased, $\mathrm{Mg}$ and Fe significantly decreased. Correlation analysis showed that Mn was positively correlated with SOD (with the exception of $2 \%$ treatment) and CAT ( $p<$ $0.01)$, and negatively correlated with $\mathrm{Cd}$ uptake $(p<0.01)$. It implied that the increase of $\mathrm{Mn}$ induced by C14 alkane stress was an important reason for the decrease of Cd uptake.

\section{Introduction}

With the rapid industrialization and urbanization, soil contaminated with heavy metals and organic pollutants has become a severe environmental and human health concerns (Dong et al., 2013; Agnello et al., 2016). Among these heavy metals, cadmium (Cd) is one of the most toxic elements, which can induce renal dysfunction, cytotoxicity and carcinogenicity in humans upon persistent exposure (Zeng et al., 2020). Petroleum hydrocarbon pollutants are recalcitrant compounds and are classified as priority pollutants (Varjani, 2017). The effects of $\mathrm{Cd}$ and petroleum on fauna and flora are difficult to predict and requires urgent remediation of the co-contaminated soil. Phytoremediation, which has been recognized as a green emerging technology, is a cost-effective, environment-friendly and aesthetically pleasing approach for removing toxic contaminants from polluted soils (Li et al., 2021). The main mechanism involved in the phytoremediation of petroleum is the biodegradation by microorganisms stimulated by rhizosphere (Wang et al., 2011). The phytoremediation of heavy metals is mainly based on the plants to uptake and accumulate contaminants from soil to plant tissues (Chaney et al., 1997).

Cd and petroleum (especially low molecular weight petroleum components) contamination usually leads to impaired growth, decreased production of photosynthetic pigments, imbalanced nutrient uptake, and oxidative damage in plants, which are mainly caused by the production of excess reactive oxygen species (ROS) (Adam and Duncan, 2002; Cui et al., 2016; Xie et al., 2018; Zeng et al., 2020). Plants can actively regulate antioxidant activities to defend against the stress condition (Ahammed et al., 2015). Several antioxidant enzymes, such as superoxide dismutase (SOD), catalase (CAT), and peroxidase (POD) are used to regulate the presence of ROS in plant tissues (Gao et al., 2018). Meanwhile, phytoremediation processes might be influenced by interactive effects of multiple pollutants on soil processes, plant growth, and rhizosphere biota (Wang et al., 2012a). For example, Lu et al. (Lu et al., 2014) found that the 
presence of heavy metals $\left(\mathrm{Cu}, \mathrm{Cd}\right.$, and $\mathrm{Pb}, 100-2000 \mathrm{mg} \cdot \mathrm{kg}^{-1}$ ) significantly reduced both plant growth and pyrene dissipation in soils. It was proved that heavy metals decreased microbial biomass and shifted the community structure, thereby decreased the degradation of organic contaminants (Chigbo et al., 2013). The presence of organic pollutants could either inhibit or favor metal accumulation by plants (Lin et al., 2008; Lu et al., 2014), depending on the pollutant characteristics, plants species, plant growth stages, and experimental conditions (Zhang et al., 2011). Alkio et al. (2006) reported that PAHs can passively penetrate the root cell membranes of plants without any carrier, which can therefore facilitate the penetration of metal or metal complexes into the cells.

In the previous researches about the interactive effects of petroleum and heavy metals on phytoremediation, total petroleum hydrocarbon (TPH) and polycyclic aromatic hydrocarbon (PAHs) are the main target pollutants of petroleum (Zhang et al., 2011; Lu et al., 2014; Steliga and Kluk, 2020). Petroleum is a complex mixture of hydrocarbons and related compounds are generally classified into four fractions: aliphatics (alkanes), aromatics, polars or resins and asphaltenes (Harayama et al., 1999). Alkanes can constitute 50-95\% of crude oil, depending on the oil source (Rojo, 2009). Compared to alkanes of larger chain length (C20-C40), those of shorter chain length (C10-C20) are more toxic (Rojo, 2009; Savage et al., 2010; Xia et al., 2014), since they are easily absorbed and act at the cellular level (Baruah et al., 2014). On the other hand, previous studies showed that Chinese soils was mainly polluted by moderate and light Cd level ( $<3 \mathrm{mg} \cdot \mathrm{kg}^{-1}$ ) (Chen et al., 2015), which presented no or slight inhibitory effects on plants growth (Shentu et al., 2008; Wang et al., 2012a). However, in the presence of moderate concentration $\mathrm{Cd}$ contaminated soil, the effect of highly toxic short chain alkanes (such as $\mathrm{C} 14$ alkane) on the plant growth and $\mathrm{Cd}$ accumulation has not been reported.

Therefore, this study intends to highlight the physiological stress responses, mineral nutrient elements uptake, Cd transfer and uptake characteristics of Lolium perenne L. (ryegrass) to different levels of highly toxic short chain alkanes (take C14 alkane as an example). Ryegrass is selected based on previous studies about survival capability and remediation potential of these plant (Rees et al., 2015; Habibul et al., 2019). The main aims are as follows: (1) to determine the impact of $C 14$ alkane on the physiological response of ryegrass, including photosynthetic pigments, lipid peroxidation (MDA), antioxidative enzymes system (SOD, CAT, and POD); (2) to examine the influence of C14 alkane on the uptake of main mineral nutrient elements $(\mathrm{K}, \mathrm{Na}, \mathrm{Ca}, \mathrm{Mg}, \mathrm{Fe}, \mathrm{Mn}, \mathrm{Cu}$, and $\mathrm{Zn})$; and (3) to elucidate the influence of $\mathrm{C} 14$ alkane on phytoextraction potential of ryegrass in Cd-contaminated soil.

\section{Materials And Methods}

\section{Chemicals and soil}

All the chemicals used in this study were analytical grade or higher, which were obtained from Sinopharm Chemical Reagent Co., Ltd (China). Standard solutions of Cd and mineral nutrient elements were purchased from the National reference material (RM) Resources Network. All the solutions were prepared used ultrapure water (Milli-Q, IQ 7000, Millipore, France). 
The unpolluted soil was obtained from arable surface soil (10-20 cm depth) near Institute of Applied Ecology in Liaoning province, China. The main physicochemical properties of the unpolluted soil were analyzed and presented in Table S1 of the Supporting Information. The soil type was loamy clay soil.

\section{Experimental design}

The soil sample was air-dried and grounded to pass through a $0.84 \mathrm{~mm}$ sieve. Cadmium alone and $\mathrm{Cd}$ with various concentrations of $\mathrm{C} 14$ alkane co-contaminated soil were obtained by spiking the cadmium nitrate and C14 alkane (CAS: 629-59-4, >98\% purity). Firstly, aqueous solution of cadmium nitrate was prepared $\left(2.5 \mathrm{mg} \cdot \mathrm{L}^{-1}\right)$ and soil was mixed thoroughly with the rate of soil: solution $(\mathrm{m} / \mathrm{V})=1: 1$ and maintained in a pot at room temperature for 1 month. Thereafter, the Cd contaminated soil was air-dried again and sieved through a $0.84 \mathrm{~mm}$ sieve. The total concentration of $\mathrm{Cd}$ in the soil was analyzed and the value was $2.182 \mathrm{mg} \cdot \mathrm{kg}^{-1}$. Then, measured amounts of $\mathrm{C} 14$ alkane were dissolved in $\mathrm{n}$-hexane and thoroughly mixed into a measured amount of $\mathrm{Cd}$ contaminated soil. To ensure uniform distribution of the C14 alkane and complete volatilization of $n$-hexane, the soil was agitated in a fume hood once a day for two weeks. The concentrations of $\mathrm{C} 14$ alkane in the experimental soils were expressed as the ratio of $\mathrm{C} 14$ alkane volume $(\mathrm{ml})$ to soil mass $(\mathrm{g})$ and the final concentrations were $0.1 \%, 0.2 \%, 0.5 \%, 1.0 \%$, and $2.0 \%$.

A total of six treatments were conducted including five treatments with $\mathrm{Cd}$ and different concentrations of C14 alkane $(0.1 \%, 0.2 \%, 0.5 \%, 1.0 \%$, and $2.0 \%)$ co-contaminated soil and a control treatment with $\mathrm{Cd}$ alone contaminated soil (Table S2). The experiment tests were carried out in a rectangular pot which the dimensions are $22 \mathrm{~cm}$ (length) $\times 16 \mathrm{~cm}$ (width) $\times 12.5 \mathrm{~cm}$ (height). Each treatment was conducted with three pot replications. Each pot was loaded with approximately $4.5 \mathrm{~kg}$ contaminated dry soil and the soil was irrigated with tap water. Ryegrass seeds obtained from Suqian Sunrise Seed Industry Co., Ltd (China). The seeds were sterilized with $\mathrm{H}_{2} \mathrm{O}_{2}(30 \%, \mathrm{~V} / \mathrm{V})$ for $30 \mathrm{~min}$, and then rinsed several times with Milli-Q water before sown. Then the seeds were sown directly into the soil when the soil water content declined to approximately $18 \%$. Six rows of ryegrass were evenly sown in each pot and $2.0 \mathrm{~g}$ seeds were planted in each row. The pots were placed under an artificial light source which was provided from fluorescent lamps with average light intensity of 3000 Lux. It was run with an automatic timer to provide $16 / 8 \mathrm{~h}$ light/dark cycle. The temperature of the greenhouse was maintained at $24-26^{\circ} \mathrm{C}$ in light and $18-$ $20{ }^{\circ} \mathrm{C}$ in dark. The pots were watered every other day and no fertilizers were added.

After $60 \mathrm{~d}$ growth of plants, the leaves were collected for chlorophyll and antioxidant enzymes analysis. Then, roots and shoots of plants were harvested separately from each pot. The fresh samples were washed with tap water and rinsed with purified water, then the moisture on the samples was gently removed with blotting paper. After washed with purified water, the roots were soaked in $20 \mathrm{mM}$ ethylenediaminetetraacetic acid disodium salt $\left(\mathrm{Na}_{2}\right.$ EDTA) for $15 \mathrm{~min}$ to remove metal ions in the roots surface, then rinsed three times with purified water. The washed plant samples were heated at $105^{\circ} \mathrm{C}$ for 20 min and dried to constant weight in an oven at $70^{\circ} \mathrm{C}$. Then the dry plant biomass was measured and recorded. 


\section{Chlorophyll content}

The total chlorophyll, chlorophylls a and b, and carotenoid contents were extracted with $80 \%$ ethanol. Absorbance was determined at $470 \mathrm{~nm}, 665 \mathrm{~nm}$, and $649 \mathrm{~nm}$ using an ultraviolet visible spectrophotometer. The concentrations of chlorophylls a, chlorophylls b, and carotenoid $\left(\mathrm{mg} \cdot \mathrm{g}^{-1}\right.$ fresh leaf weight (FW)) were calculated using the equations of previous study (Lichtenthaler and Wellburn, 1983).

\section{Malondialdehyde and enzyme activity}

Level of lipid peroxidation was expressed as the content of MDA (nmol. $\left.\mathrm{g}^{-1} \mathrm{FW}\right)$. The fresh leaves were homogenized in trichloroacetic acid (TCA) solution, then reacted with thiobarbituric acid (TBA). The absorbance of the supernatant was measured at $440 \mathrm{~nm}, 532 \mathrm{~nm}$, and $600 \mathrm{~nm}$ and the MDA content were calculated according to previous study (Hodges et al., 1999). The SOD activity was measured using the nitro blue tetrazorium (NBT) method (Beauchamp and Fridovich, 1971). The fresh leaves were homogenized with $0.05 \mathrm{M}$ sodium phosphate buffer and centrifuged at $4000 \mathrm{~g}$ for $10 \mathrm{~min}$ for POD and CAT activity analysis. The POD activity was determined on the basis of guaiacol oxidation by hydrogen peroxide (Zhang et al., 2007). The CAT activity was assayed with a method as described by previous study (Zhang et al., 2005).

\section{Cd and mineral nutrient elements}

The shoots and roots of plants were digested with $\mathrm{HNO}_{3}+\mathrm{HClO}_{4}$ (Zhang et al., 2005) and the supernatant were filtered through a $0.22 \mu \mathrm{m}$ filters. Then the concentrations of $\mathrm{Cd}$ and mineral nutrient elements were analyzed by an Inductively Coupled Plasma Mass Spectrometer (ICP-MS, iCAP RQ, Thermo Fisher Scientific, USA).

Statistical analyses

The Cd uptake amount of shoot or root were calculated using the equation suggested by Wang et al. (2020):

\section{$U_{C d}=C_{C d} \times M$}

Where, $U_{C d}(\mathrm{ug})$ is the $\mathrm{Cd}$ uptake amount of shoot or root, $C_{C d}\left(\mathrm{mg} \cdot \mathrm{kg}^{-1}\right.$, dry weight) is the $\mathrm{Cd}$ concentration of shoot or root. $M(\mathrm{~g})$ is the dry weight of shoot or root.

Each treatment was conducted in triplicate and the results were reported as mean \pm SD. Analysis of variance ANOVA was used to detect the differences among treatments. Statistical significance was defined as $p<0.05$ (IBM SPSS Statistics 22, New York, USA). Bivariate correlations analyses were 
performed and significance was accepted at $p<0.05$ in all cases (Person's correlation). Principal component analysis (PCA) were performed to assess the possible correlations among mineral nutrient elements and chlorophyll content, antioxidant enzymes activity. Redundancy analysis (RDA) were performed to determine the factors influenced Cd uptake. PCA and RDA were conducted using R (version 4.0.2). Origin software (version 8.0, Origin Lab Corporation, Northampton, USA) was used to prepare graphs.

\section{Results And Discussion}

\section{Effect of $\mathrm{C} 14$ alkane on biomass of ryegrass}

Biomass yield were measured to examine the effects of $\mathrm{C} 14$ alkane on the health of ryegrass. As shown in Fig. 1, the biomass yield of shoot and root of ryegrass gradually decreased with the increasing of $\mathrm{C} 14$ alkane concentration. The significantly decrease of shoot biomass was occurred at $0.2 \% \mathrm{C} 14$ alkane treatment, while at $0.5 \% \mathrm{C} 14$ alkane treatment a more dramatically inhibitory effect was observed and the percentage of inhibition was approximately $58.67 \%$ of control treatment. The ryegrass root biomass also significantly decreased when $\mathrm{C} 14$ alkane were added in soil, the percentage of decrease at $2 \% \mathrm{C} 14$ alkane treatment was approximately $46.34 \%$ of control treatment. Toxic effects of organic compounds on plant growth and biomass have already been observed in many plants (Xie et al., 2017; Gao et al., 2018; Xi et al., 2018), which was consistent with this research.

\section{Effect of C14 alkane on Cd concentration and accumulation of ryegrass}

After different concentration of $\mathrm{C} 14$ alkane treatments, the Cd concentration and uptake amount in the shoot and root of ryegrass were shown in Fig. 1. The results indicated that the presence of $\mathrm{C} 14$ alkane in soil significantly affected the $\mathrm{Cd}$ concentration and uptake amount of ryegrass. Compared with control treatment, $\mathrm{Cd}$ concentration in shoot and root of ryegrass significantly increased at $0.1 \% \mathrm{C} 14$ alkane treatment, then gradually decreased with the increase of $\mathrm{C} 14$ alkane concentration. When $\mathrm{C} 14$ alkane concentration increased to $1 \%$, Cd content in shoot of ryegrass was significantly lower than that in control treatment. However, Cd content in root of ryegrass at 2\% C14 alkane treatment presented no significant difference with control treatment.

With the increase of C14 alkane concentration, the variation trend of Cd uptake amount in shoot and root of ryegrass were similar with that of $\mathrm{Cd}$ concentration. The maximum value of $\mathrm{Cd}$ uptake amount was observed at $0.1 \% \mathrm{C} 14$ alkane treatment, which was $30.17 \mu \mathrm{g} \cdot \mathrm{pot}^{-1}$ in shoot and $4.44 \mu \mathrm{g} \cdot \operatorname{pot}^{-1}$ in root. Compared with the control, Cd uptake amount at $0.1 \% \mathrm{C} 14$ alkane treatment were increased by $69.9 \%$ in shoot and $48.8 \%$ in root. A similar phenomenon was found by Lu et al. that the pyrene addition significantly increased $\mathrm{Cu}, \mathrm{Cd}$, and $\mathrm{Pb}$ concentrations of both roots and shoots (Lu et al., 2014). However, Cd uptake amount gradually decreased with the increase of C14 alkane concentration. When the C14 
alkane concentration increased to $0.5 \%$, Cd uptake amount in shoots of ryegrass was significantly lower than that at control treatment. Compared with the control treatment, Cd uptake amount at 2\% C14 alkane treatment were reduced by $85.1 \%$ in shoot and $47.8 \%$ in root. At $0.5 \%$ C14 alkane treatment, the decrease of ryegrass biomass was the main reason for the decrease of $\mathrm{Cd}$ uptake amount in shoot. When $\mathrm{C} 14$ alkane concentration increased to $1 \%$, both biomass and Cd concentration had a significant effect on the decrease of Cd uptake amount in shoot. Gao and Zhu (2004) also reported that the concentrations of phenanthrene and pyrene above certain levels (133 and $172 \mathrm{mg} \cdot \mathrm{kg}^{-1} \mathrm{DW}$ ) decreased dry weight of 12 plant species.

\section{Effect of C14 alkane on chlorophyll content of ryegrass}

Chlorophyll a, chlorophyll b, and carotenoid concentrations in leaves of ryegrass grown in different concentration of $\mathrm{C} 14$ alkane contaminated soil were presented in Fig. 2. The results revealed that chlorophyll contents in ryegrass were gradually diminished with increasing concentration of $\mathrm{C} 14$ alkane, although differences in chlorophyll contents for some treatments were not significant. Compared with the control treatment, chlorophyll a, chlorophyll b, and carotenoid concentrations of ryegrass at $2 \% \mathrm{C} 14$ alkane treatment were reduced by $16.37 \%, 23.16 \%$, and $16.60 \%$, respectively. The concentration of C14 alkane had a more significant effect on chlorophyll $b$ than that on chlorophyll a and carotenoid.

\section{Effect of C14 alkane on membrane lipid peroxidation and antioxidant enzyme activities of ryegrass}

The MDA concentration was used as the general indicator of the extent of membrane lipid peroxidation (Ahammed et al., 2012). Elevation of the MDA contents indicated higher lipid peroxidation and overproduction of reactive oxygen species (ROS) resulting from environment stress (Wang et al., 2006; Choudhary et al., 2011; Xi et al., 2018). The MDA contents in leaves of ryegrass grown in different concentration of $\mathrm{C} 14$ alkane contaminated soil were presented in Fig. 3a. Compared with the control treatment, the MDA contents in ryegrass significantly increased in all the $\mathrm{C} 14$ alkane treatments. When the $\mathrm{C} 14$ alkane concentration was less than $0.5 \%$, the increase percentage of MDA concentrations were approximately $60 \%$ of control treatment, and no significant disparities among different $\mathrm{C} 14$ alkane treatments were shown. When the $\mathrm{C} 14$ alkane concentration increased to $1 \%$, the MDA concentrations sharply increased. The highest MDA content was observed at $2 \% \mathrm{C} 14$ alkane treatment, which was $160.2 \%$ higher than that in control treatment.

To prevent cell damage, antioxidant enzyme systems were elevated among plants for coping with environmental stress. SOD, CAT, and POD were three vital enzymes that can scavenge ROS in plant cells. SOD was the first defense against ROS since it can catalyze the conversion of superoxide radicals into hydrogen peroxide (Gao et al., 2018). The SOD activity in the leaves of ryegrass were shown in Fig. 3b. The SOD activity first gradually increased with an increase of $\mathrm{C} 14$ alkane concentration. The maximum 
value of SOD activity was observed at $1 \%$ C14 alkane treatment, which was increased by $4082 \%$ compared with that in the control. While, the superoxide radicals as well as other radicals can inactivate antioxidant enzymes (Gao et al., 2017). The SOD activity significantly decreased when the $\mathrm{C} 14$ alkane concentration were higher than $1 \%$. It suggested that the superoxide radical production exceeded the ability of SOD to scavenge it.

The CAT activity was the primary $\mathrm{H}_{2} \mathrm{O}_{2}$ scavenging enzyme in plant cells, $\mathrm{H}_{2} \mathrm{O}_{2}$ can be reduced to $\mathrm{H}_{2} \mathrm{O}$ and $\mathrm{O}_{2}$ by it ( $\mathrm{Li}$ and $\mathrm{Yi}, 2012$ ). Compared with control treatment, the CAT activity had a slight increase when $\mathrm{C} 14$ alkane concentration was in the range of $0.1-1 \%$, then significantly increased at $2 \% \mathrm{C} 14$ alkane treatment (Fig. 3c). The CAT activity at 2\% C14 alkane treatment increased by $121.8 \%$ compared with that in the control. The CAT results were consistent with the increase of MDA contents at $2 \% \mathrm{C} 14$ alkane treatment as shown above. The elevated of CAT activity was associated with the increase of ROS, which was a signal molecule inducing the expression of CAT gene (Wang et al., 2012b).

POD was a defense enzyme that can scavenge highly toxic ROS major produced by SOD to plant cells (Zhou et al., 2016). POD had been reported to reduce $\mathrm{H}_{2} \mathrm{O}_{2}$ using phenolic compounds or flavonoids as donors of electron (Mitsou et al., 2006). The POD activity in the leaves of ryegrass at different C14 alkane concentration treatment was shown in Fig. 3d. Compared with the control treatment, the POD activity showed a slight increase trend at $0.1 \% \mathrm{C} 14$ alkane treatment, then gradually decreased at the following two $\mathrm{C} 14$ alkane treatment $(0.2 \%$ and $0.5 \%)$, and finally showed an increase trend again when the $\mathrm{C} 14$ alkane concentration was higher than $0.5 \%$ (Fig. 3d). The minimum value of POD activity observed at $0.5 \%$ C14 alkane treatment, which was $26.06 \%$ lower than that in control treatment. The results indicated that $\mathrm{C} 14$ alkane concentration just had a little impact on the POD activity of ryegrass. Base above analysis, we can conclude that SOD and CAT were the main antioxidant enzyme in ryegrass to prevent the $\mathrm{C} 14$ alkane stress.

\section{Effect of C14 alkane on mineral nutrient elements uptake of ryegrass}

The concentrations of mineral nutrient elements ( $\mathrm{K}, \mathrm{Na}, \mathrm{Ca}$, and $\mathrm{Mg}, \mathrm{Fe}, \mathrm{Mn}, \mathrm{Cu}$, and $\mathrm{Zn}$ ) in shoots of ryegrass grown in different concentration of C14 alkane contaminated soil were shown in Fig. 4. The results indicated that the presence of $\mathrm{C} 14$ alkane in soil affected the uptake of all the measured elements. As shown in Fig. $4 \mathrm{a}$, the $\mathrm{K}$ concentration in shoots of ryegrass showed a fluctuant trend with the increase of $\mathrm{C} 14$ alkane concentration. While the $\mathrm{Na}$ concentration decreased in the ryegrass grown in all the $\mathrm{C} 14$ alkane contaminated soil. The $\mathrm{Ca}$ concentration showed a slight decrease and no conspicuous changes was observed between different concentration of $\mathrm{C} 14$ alkane treatment. The $\mathrm{Mg}$ concentration obviously decreased in different $\mathrm{C} 14$ alkane treatments and showed a fluctuant trend with the increase of $\mathrm{C} 14$ alkane concentration. The Fe concentration significantly decreased at all the $\mathrm{C} 14$ alkane treatments compared with control treatment. The Mn concentration presented a gradually increase trend with the 
increase of $\mathrm{C} 14$ alkane concentration. The variation trend of $\mathrm{Cu}$ and $\mathrm{Zn}$ concentration in ryegrass were similar and showed no pronounced changes with the increase of $\mathrm{C} 14$ alkane concentration.

The correlation of chlorophyll content, antioxidant enzyme activities and mineral nutrient elements in the shoots was analyzed and listed in table S3. In addition, PCA was used to assess the relationship among the chlorophyll content, antioxidant enzyme activities and mineral nutrient elements (Fig. 5). The cumulative contribution ratio of PCA from the first two principal component were $74.5 \%$. As the results showed, chlorophyll content and antioxidant enzyme activities were correlated with many mineral nutrient elements. Specifically, chlorophyll contents were positively correlated with $\mathrm{K}, \mathrm{Na}, \mathrm{Ca}, \mathrm{Mg}, \mathrm{Fe}$ and negatively correlated with Mn. MAD was positively correlated with $\mathrm{Mn}$ and negatively correlated with $\mathrm{K}$, $\mathrm{Na}, \mathrm{Mg}$, Fe. POD activity was positively correlated with $\mathrm{Cu}$ and $\mathrm{Zn}$. CAT activity was positively correlated with $\mathrm{Mn}, \mathrm{Zn}$ and negatively correlated with $\mathrm{K}, \mathrm{Na}$. SOD was negatively correlated with $\mathrm{K}, \mathrm{Ca}, \mathrm{Mg}$.

With the increased of $\mathrm{C} 14$ alkane concentration, the Mn concentration in the shoots of ryegrass gradually increased (Fig. 4f). Correlation analysis showed that the Mn concentration was significantly and positively correlated with MDA (Table S3 and Fig. 5). These results indicated that the oxidative stress of C14 alkane induced the increase of Mn concentration in shoot of ryegrass. Carvalho et al. (2019) also reported a similar phenomenon that $\mathrm{Mn}$ concentration significantly increased after $\mathrm{Cd}$ exposure. Previous studies had proved that supplemental $\mathrm{Mn}$ can reduce plants oxidative damage induced by $\mathrm{Cd}$ or salt (Cramer and Nowak, 1992; Rahman et al., 2016). Manganese played a vital role as cofactor in Mn-SOD and Mn-CAT, which participate in the plant's defense against oxidative stress (Pittman, 2005). Meanwhile Mn can act as a scavenger of superoxide and hydrogen peroxide (Pittman, 2005; Millaleo et al., 2010). In the present study, Mn concentration was significantly correlated $(p<0.01)$ with CAT activity (Table S3, Fig. 5), which was consistent with previous researches (Rahman et al., 2016). However, no significantly correlation was observed between Mn concentration and SOD activity in shoots of ryegrass. In the $2 \%$ C14 alkane treatments, SOD activity in ryegrass dramatically decreased (Fig. 3b), which may be inactivated by superoxide radicals and other radicals (Ahammed et al., 2012). With the exception of $2 \%$ treatment, Mn concentration was significantly and positively correlated with SOD activity $(r=0.752, p<$ 0.01). We can conclude that the increased Mn concentration in shoots of ryegrass was a self-protection mechanism to reduce $\mathrm{C} 14$ alkane toxicity.

When the ryegrass was grown in the $\mathrm{C} 14$ alkane contaminated soil, $\mathrm{Mg}$ and Fe concentration in the shoot significantly decreased (Fig. 4de). The increasing uptake of $\mathrm{Mn}$ may be a reason for inhibiting the uptake of $\mathrm{Mg}$ and $\mathrm{Fe}$ (Heenan and Campbell, 1981). The results were similar to the previous studies which found that $\mathrm{Mn}$ concentration in the stem tissues of Lactuca spp. significantly increased but other essential micronutrients decreased under the stress of Cd (Ramos et al., 2002). Mg was an essential macroelement participating in the enzymatic reactions and photosynthesis as a structural component of the chlorophyll molecule (McSwain et al., 1976; Wang et al., 2017). Fe, which located mainly in the photosynthetic membranes, had a significantly influence on the structure and function of chloroplasts (Zembala et al., 2010; Liu et al., 2017). Combined with the results of the correlation analysis, we can 
conjecture that the decrease of $\mathrm{Mg}$ and Fe concentrations in shoots of ryegrass under $\mathrm{C} 14$ alkane stress was an important reason for the decrease of chlorophyll content and ryegrass growth.

Cd uptake amount in the shoot of plants was an important parameter for determining the efficiency of phytoremediation, since this part can be harvested easily and treated. Biomass and Cd content in plants were two important indices that affected $\mathrm{Cd}$ uptake amount. As indicated above, Cd uptake amount obviously increased at $0.1 \% \mathrm{C} 14$ alkane treatment. The bioremediation of $\mathrm{C} 14$ alkane may decrease soil pH with a consequent solubilization of metals (Chen et al., 2004). In addition, Alkio et al. reported that PAHs can passively penetrate the root cell membranes of plants without any carrier, which can therefore facilitate the penetration of metal or metal complexes into the cells (Alkio et al., 2006). The C14 alkane might also facilitate the penetration of metal into the cells in a similar way as PAHs did.

However, Cd uptake amount gradually decreased with the increase of C14 alkane concentration. In order to reveal the primary factors that affected the $\mathrm{Cd}$ uptake, the relationship between the $\mathrm{Cd}$ uptake indices (biomass, $\mathrm{Cd}$ content, $\mathrm{Cd}$ uptake amount) and chlorophyll content, antioxidant enzyme activities, mineral nutrient elements were studied using an RDA (Fig. 6) and Pearson's correlation (Table S4). According to the RDA of the Cd uptake with respect to the mineral nutrient elements (Fig. 6a), the first two ordination axes explained $95.48 \%$ of the total variation in the $\mathrm{Cd}$ accumulation, with the first axis explaining $93.87 \%$ and the second axis explaining $1.61 \%$. Cd uptake amount showed a positive correlation with Fe and $\mathrm{Mg}$, but a negative correlation with $\mathrm{Mn}$. According to the RDA of the Cd uptake with respect to the chlorophyll content and antioxidant enzyme activities (Fig. 6b), the first two ordination axes explained $88.25 \%$ of the total variation in the $\mathrm{Cd}$ uptake, with the first axis explaining $86.92 \%$ and the second axis explaining $1.33 \%$. Cd uptake amount showed a positive correlation with chlorophyll content, but a negative correlation with MAD.

The growth characteristics of plants were one of the most important indicators used for the phytoremediation of contaminated soil (Zeng et al., 2020). As table S4 and Fig. 6 shown, significant positive relationships were discovered between biomass and chlorophyll contents. The chlorophyll contents reflect the photosynthesis ability of plants, which was one of the most essential processes of plant growth and development (Ahammed et al., 2012; Zeng et al., 2020). Meanwhile, biomass was positively correlated with $\mathrm{K}, \mathrm{Na}, \mathrm{Ca}, \mathrm{Fe}, \mathrm{Mg}$. As analyzed above, chlorophyll contents were also positively correlated with $\mathrm{K}, \mathrm{Na}, \mathrm{Ca}, \mathrm{Mg}$ and $\mathrm{Fe}$, and we conjectured that the decrease of $\mathrm{Mg}$ and $\mathrm{Fe}$ was an important reason for the decrease of chlorophyll content. In other words, the decrease of $\mathrm{Mg}$ and Fe was an important reason for the decrease of biomass, which was consistent with previous results (Nazar et al., 2012).

In this study, Cd concentration in the shoot of ryegrass was positively correlated with $\mathrm{K}, \mathrm{Na}$, chlorophyll a and negatively correlated with Mn, MAD and CAT (Table S4 and Fig. 6). Previous studies had proved that addition of $\mathrm{K}$ as KCl or $\mathrm{K}_{2} \mathrm{SO}_{4}$ increased Cd concentrations in plant shoots of both Brookton and Krichauff (Zhao et al., 2004). But K and Na concentration in the shoot of ryegrass just had a slight decrease when $\mathrm{C} 14$ alkane concentration was in the range of $0.1-0.5 \%$ (Fig. $4 \mathrm{a}$, b). In addition, Cd did not 
have a known biological function in plants and enters plant cells mainly via cation channels of $\mathrm{Ca}, \mathrm{Mg}$ and Fe or transporters of other divalent cations (Huang et al., 2020). Therefore, we believed that the influence of $\mathrm{K}$ and $\mathrm{Na}$ on the $\mathrm{Cd}$ concentration in the shoot of ryegrass was limited.

Many researchers observed competitive uptake between $\mathrm{Cd}$ and $\mathrm{Mn}, \mathrm{Ca}, \mathrm{Zn}, \mathrm{Fe}$, because $\mathrm{Cd}$ and $\mathrm{Mn}, \mathrm{Ca}$, $\mathrm{Zn}$, Fe use some common transporters for their uptake and translocation in plants (Rahman et al., 2016; Huang et al., 2020). As mentioned above, Mn concentration in the shoot of ryegrass significantly increased with the increase of $\mathrm{C} 14$ alkane concentration (Fig. 4f). Previous studies using distinct plant species evidenced that the increased shoot Mn accumulation reduced Cd uptake (Carvalho et al., 2019). In the presence of $\mathrm{Cd}$, Peng et al. (2008) proved that adding Mn to the solution significantly reduced the concentrations of $\mathrm{Cd}$ in all organs of the plant. Thus, the increase of $\mathrm{Mn}$ in the shoots of ryegrass might be an important reason for the decrease of Cd concentration (Fig. 7).

\section{Conclusions}

In this study, the obtained results indicated that $0.1 \% \mathrm{C} 14$ alkane treatment significantly increased $\mathrm{Cd}$ uptake amount, then gradually decreased with the increase of $\mathrm{C} 14$ alkane concentration. Under the stress of $\mathrm{C} 14$ alkane, reactive oxygen species in the shoot of ryegrass significantly increased. To prevent C14 alkane toxicity, SOD and CAT activity significantly increased. Meanwhile, C14 alkane stress induced the increase of $\mathrm{Mn}$ content, which might be play a critical role in defense $\mathrm{C} 14$ alkane toxicity. Cadmium, $\mathrm{Fe}$ and $\mathrm{Mg}$ content in the shoot of ryegrass significantly decreased as the competitive uptake with $\mathrm{Mn}$. The decrease of $\mathrm{Mg}$ and Fe concentrations was an important reason for the decrease of chlorophyll content and ryegrass growth. Thus, we conclude that the increase of Mn concentration induced by the stress of C14 alkane directly or indirectly affected the growth and Cd content of ryegrass, and ultimately influenced the Cd phytoremediation efficiency. This study will help us to understand the influence mechanism of C14 alkane on phytoremediation efficiency of $\mathrm{Cd}$.

\section{Declarations}

\section{Acknowledgements}

This work was supported by China Postdoctoral Science Foundation (No. 2019M652453), National Natural Science Foundation of China (No. 41977140), Qilu University of Technology (Shandong Academy of Sciences) Youth Doctoral Cooperation Fund Project (No. 2018BSHZ0016), and Liao Ning Revitalization Talents Program (No. XLYC1802111).

\section{Author contribution}

Lizhu Yuan: Performed the experiments, Data processing, Draft preparation. Penghong Guo: Reviewing, Revising, Editing the manuscript. Shuhai Guo: Conceived and designed experiments. Jianing Wang: 
Conceptualization, Methodology. Yujie Huang: Participate in some tests. All authors read and approved the final manuscript.

\section{Availability of data and materials}

The authors declare that (the/all other) data supporting the findings of this study are available within the article (and its supplementary information files).

\section{Ethics approval and consent to participate}

Not applicable.

\section{Consent for publication}

Not applicable.

\section{Competing interests}

The authors declares no conflicts of interest.

\section{References}

1. Adam, G., Duncan, H., 2002. Influence of diesel fuel on seed germination. Environ. Pollut. 120, 363370.

2. Agnello, A.C., Bagard, M., van Hullebusch, E.D., Esposito, G., Huguenot, D., 2016. Comparative bioremediation of heavy metals and petroleum hydrocarbons co-contaminated soil by natural attenuation, phytoremediation, bioaugmentation and bioaugmentation-assisted phytoremediation. Sci. Total. Environ. 563-564, 693-703.

3. Ahammed, G.J., Li, X., Xia, X.-J., Shi, K., Zhou, Y.-H., Yu, J.-Q., 2015. Enhanced photosynthetic capacity and antioxidant potential mediate brassinosteriod-induced phenanthrene stress tolerance in tomato. Environ. Pollut. 201, 58-66.

4. Ahammed, G.J., Wang, M.-M., Zhou, Y.-H., Xia, X.-J., Mao, W.-H., Shi, K., Yu, J.-Q., 2012. The growth, photosynthesis and antioxidant defense responses of five vegetable crops to phenanthrene stress. Ecotox. Environ. Safe. 80, 132-139.

5. Alkio, M., Tabuchi, T.M., Wang, X., Colón-Carmona, A., 2006. Stress responses to polycyclic aromatic hydrocarbons in Arabidopsis include growth inhibition and hypersensitive response-like symptoms. J. Exp. Bot. 
6. Baruah, P., Saikia, R.R., Baruah, P.P., Deka, S., 2014. Effect of crude oil contamination on the chlorophyll content and morpho-anatomy of Cyperus brevifolius (Rottb.) Hassk. Environ. Sci. Pollut. R 21, 12530-12538.

7. Beauchamp, C., Fridovich, I., 1971. Superoxide dismutase: Improved assays and an assay applicable to acrylamide gels. Anal. Biochem. 44, 276-287.

8. Carvalho, M.E.A., Piotto, F.A., Franco, M.R., Rossi, M.L., Martinelli, A.P., Cuypers, A., Azevedo, R.A., 2019. Relationship between $\mathrm{Mg}, \mathrm{B}$ and $\mathrm{Mn}$ status and tomato tolerance against Cd toxicity. J. Environ. Manage. 240, 84-92.

9. Chaney, R.L., Malik, M., Li, Y.M., Brown, S.L., Brewer, E.P., Angle, J.S., Baker, A.J.M., 1997. Phytoremediation of soil metals. Curr. Opin. Biotechnol. 8, 279-284.

10. Chen, H., Teng, Y., Lu, S., Wang, Y., Wang, J., 2015. Contamination features and health risk of soil heavy metals in China. Sci. Total. Environ. 512-513, 143-153.

11. Chen, Y.X., Lin, Q., He, Y.F., Tian, G.M., 2004. Behavior of Cu and Zn under combined pollution of 2,4dichlorophenol in the planted soil. Plant Soil 261, 127-134.

12. Chigbo, C., Batty, L., Bartlett, R., 2013. Interactions of copper and pyrene on phytoremediation potential of Brassica juncea in copper-pyrene co-contaminated soil. Chemosphere 90, 2542-2548.

13. Choudhary, S.P., Kanwar, M., Bhardwaj, R., Gupta, B.D., Gupta, R.K., 2011. Epibrassinolide ameliorates $\mathrm{Cr}(\mathrm{VI})$ stress via influencing the levels of indole-3-acetic acid, abscisic acid, polyamines and antioxidant system of radish seedlings. Chemosphere 84, 592-600.

14. Cramer, G.R., Nowak, R.S., 1992. Supplemental manganese improves the relative growth, net assimilation and photosynthetic rates of salt-stressed barley. Physiol. Plantarum. 84, 600-605.

15. Cui, B., Zhang, X., Han, G., Li, K., 2016. Antioxidant Defense Response and Growth Reaction of Amorpha fruticosa Seedlings in Petroleum-Contaminated Soil. Water Air. Soil Poll. 227, 121.

16. Dong, Z.-Y., Huang, W.-H., Xing, D.-F., Zhang, H.-F., 2013. Remediation of soil co-contaminated with petroleum and heavy metals by the integration of electrokinetics and biostimulation. J. Hazard. Mater. 260, 399-408.

17. Gao, M., Dong, Y., Zhang, Z., Song, W., Qi, Y., 2017. Growth and antioxidant defense responses of wheat seedlings to di-n-butyl phthalate and di (2-ethylhexyl) phthalate stress. Chemosphere 172, 418428.

18. Gao, M., Liu, Y., Dong, Y., Song, Z., 2018. Photosynthetic and antioxidant response of wheat to di(2ethylhexyl) phthalate (DEHP) contamination in the soil. Chemosphere 209, 258-267.

19. Gao, Y., Zhu, L., 2004. Plant uptake, accumulation and translocation of phenanthrene and pyrene in soils. Chemosphere 55, 1169-1178.

20. Habibul, N., Chen, J.-J., Hu, Y.-Y., Hu, Y., Yin, H., Sheng, G.-P., Yu, H.-Q., 2019. Uptake, accumulation and metabolization of 1-butyl-3-methylimidazolium bromide by ryegrass from water: Prospects for phytoremediation. Water Res. 156, 82-91. 
21. Harayama, S., Kishira, H., Kasai, Y., Shutsubo, K., 1999. Petroleum biodegradation in marine environments. J. Mol. Microb. Biotech. 1, 63-70.

22. Heenan, D.P., Campbell, L.C., 1981. Influence of potassium and manganese on growth and uptake of magnesium by soybeans (Glycine max (L.) Merr. cv. Bragg). Plant Soil 61, 447-456.

23. Hodges, D.M., DeLong, J.M., Forney, C.F., Prange, R.K., 1999. Improving the thiobarbituric acidreactive-substances assay for estimating lipid peroxidation in plant tissues containing anthocyanin and other interfering compounds. Planta 207, 604-611.

24. Huang, R., Dong, M., Mao, P., Zhuang, P., Paz-Ferreiro, J., Li, Y., Li, Y., Hu, X., Netherway, P., Li, Z., 2020. Evaluation of phytoremediation potential of five $\mathrm{Cd}$ (hyper)accumulators in two Cd contaminated soils. Sci. Total. Environ. 721, 137581.

25. Li, L., Yi, H., 2012. Effect of sulfur dioxide on ROS production, gene expression and antioxidant enzyme activity in Arabidopsis plants. Plant Physiol. Biochem. 58, 46-53.

26. Li, Y., Xie, T., Zha, Y., Du, W., Yin, Y., Guo, H., 2021. Urea-enhanced phytoremediation of cadmium with willow in pyrene and cadmium contaminated soil. J. Hazard. Mater. 405, 124257.

27. Lichtenthaler, H., Wellburn, A.R., 1983. Determinations of total carotenoids and chlorophylls a and b of leaf extracts in different solvents. Biochem. Soc. Trans. 11, 591-592.

28. Lin, Q., Shen, K.-L., Zhao, H.-M., Li, W.-H., 2008. Growth response of Zea mays L. in pyrene-copper cocontaminated soil and the fate of pollutants. J. Hazard. Mater. 150, 515-521.

29. Liu, H., Zhang, C., Wang, J., Zhou, C., Feng, H., Mahajan, M.D., Han, X., 2017. Influence and interaction of iron and cadmium on photosynthesis and antioxidative enzymes in two rice cultivars. Chemosphere 171, 240-247.

30. Lu, M., Zhang, Z.-Z., Wang, J.-X., Zhang, M., Xu, Y.-X., Wu, X.-J., 2014. Interaction of Heavy Metals and Pyrene on Their Fates in Soil and Tall Fescue (Festuca arundinacea). Environ. Sci. Technol. 48, 11581165.

31. McSwain, B.D., Tsujimoto, H.Y., Arnon, D.I., 1976. Effects of magnesium and chloride ions on lightinduced electron transport in membrane fragments from a blue-green alga. Bba-biomembranes 423 , 313-322.

32. Millaleo, R., Reyes-Díaz, M., Ivanov, A., Mora, M., Alberdi, M., 2010. Manganese as essential and toxic element for plants: transport, accumulation and resistance mechanisms. J. Soil Sci. Plant Nut. 10, 470-481.

33. Mitsou, K., Koulianou, A., Lambropoulou, D., Pappas, P., Albanis, T., Lekka, M., 2006. Growth rate effects, responses of antioxidant enzymes and metabolic fate of the herbicide Propanil in the aquatic plant Lemna minor. Chemosphere 62, 275-284.

34. Nazar, R., Iqbal, N., Masood, A., Khan, M.I.R., Syeed, S., Khan, N.A., 2012. Cadmium toxicity in plants and role of mineral nutrients in its alleviation. Am. J. Plant Sci. 3, 1476-1489.

35. Peng, K., Luo, C., You, W., Lian, C., Li, X., Shen, Z., 2008. Manganese uptake and interactions with cadmium in the hyperaccumulator-Phytolacca Americana L. J. Hazard. Mater. 154, 674-681. 
36. Pittman, J.K., 2005. Managing the manganese: molecular mechanisms of manganese transport and homeostasis. New Phytol. 167, 733-742.

37. Rahman, A., Nahar, K., Hasanuzzaman, M., Fujita, M., 2016. Manganese-induced cadmium stress tolerance in rice seedlings: Coordinated action of antioxidant defense, glyoxalase system and nutrient homeostasis. Cr. Biol. 339, 462-474.

38. Ramos, I., Esteban, E., Lucena, J.J., Gárate, A.n., 2002. Cadmium uptake and subcellular distribution in plants of Lactuca sp. Cd-Mn interaction. Plant Sci. 162, 761-767.

39. Rees, F., Germain, C., Sterckeman, T., Morel, J.-L., 2015. Plant growth and metal uptake by a nonhyperaccumulating species (Lolium perenne) and a Cd-Zn hyperaccumulator (Noccaea caerulescens) in contaminated soils amended with biochar. Plant Soil 395, 57-73.

40. Rojo, F., 2009. Degradation of alkanes by bacteria. Environ. Microbiol. 11, 2477-2490.

41. Savage, K.N., Krumholz, L.R., Gieg, L.M., Parisi, V.A., Suflita, J.M., Allen, J., Philp, R.P., Elshahed, M.S., 2010. Biodegradation of low-molecular-weight alkanes under mesophilic, sulfate-reducing conditions: metabolic intermediates and community patterns. Fems Microbiol. Ecol. 72, 485-495.

42. Shentu, J., He, Z., Yang, X.-E., Li, T., 2008. Accumulation Properties of Cadmium in a Selected Vegetable-Rotation System of Southeastern China. J. Agr. Food Chem. 56, 6382-6388.

43. Steliga, T., Kluk, D., 2020. Application of Festuca arundinacea in phytoremediation of soils contaminated with Pb, Ni, Cd and petroleum hydrocarbons. Ecotox. Environ. Safe. 194, 110409.

44. Varjani, S.J., 2017. Microbial degradation of petroleum hydrocarbons. Bioresource Technol. 223, 277286.

45. Wang, C., Zhao, Y., Zheng, R., Ding, X., Wei, W., Zuo, Z., Chen, Y., 2006. Effects of tributyltin, benzo[a]pyrene, and their mixture on antioxidant defense systems in Sebastiscus marmoratus. Ecotox. Environ. Safe. 65, 381-387.

46. Wang, J., Chen, X., Chi, Y., Chu, S., Hayat, K., Zhi, Y., Hayat, S., Terziev, D., Zhang, D., Zhou, P., 2020. Optimization of NPK fertilization combined with phytoremediation of cadmium contaminated soil by orthogonal experiment. Ecotox. Environ. Safe. 189, 109997.

47. Wang, K., Zhu, Z., Huang, H., Li, T., He, Z., Yang, X., Alva, A., 2012a. Interactive effects of Cd and PAHs on contaminants removal from co-contaminated soil planted with hyperaccumulator plant Sedum alfredii. J. Soil. Sediment. 12, 556-564.

48. Wang, L., Huang, X., Ma, F., Ho, S.-H., Wu, J., Zhu, S., 2017. Role of Rhizophagus irregularis in alleviating cadmium toxicity via improving the growth, micro- and macroelements uptake in Phragmites australis. Environ. Sci. Pollut. R 24, 3593-3607.

49. Wang, P., Zhang, S., Wang, C., Lu, J., 2012b. Effects of Pb on the oxidative stress and antioxidant response in a $\mathrm{Pb}$ bioaccumulator plant Vallisneria natans. Ecotox. Environ. Safe. 78, 28-34.

50. Wang, Z., Xu, Y., Zhao, J., Li, F., Gao, D., Xing, B., 2011. Remediation of petroleum contaminated soils through composting and rhizosphere degradation. J. Hazard. Mater. 190, 677-685. 
51. Xi, Y., Song, Y., Liu, H., Johnson, D.M., Huang, Y., 2018. Selenium enhanced degradation of diesel by Erigeron annuus. J. Soil. Sediment. 18, 1906-1914.

52. Xia, W., Du, Z., Cui, Q., Dong, H., Wang, F., He, P., Tang, Y., 2014. Biosurfactant produced by novel Pseudomonas sp. WJ6 with biodegradation of n-alkanes and polycyclic aromatic hydrocarbons. J. Hazard. Mater. 276, 489-498.

53. Xie, W., Li, R., Li, X., Liu, P., Yang, H., Wu, T., Zhang, Y., 2018. Different responses to soil petroleum contamination in monocultured and mixed plant systems. Ecotox. Environ. Safe. 161, 763-768.

54. Xie, W., Zhang, Y., Li, R., Yang, H., Wu, T., Zhao, L., Lu, Z., 2017. The responses of two native plant species to soil petroleum contamination in the Yellow River Delta, China. Environ. Sci. Pollut. R 24, 24438-24446.

55. Zembala, M., Filek, M., Walas, S., Mrowiec, H., Kornaś, A., Miszalski, Z., Hartikainen, H., 2010. Effect of selenium on macro- and microelement distribution and physiological parameters of rape and wheat seedlings exposed to cadmium stress. Plant Soil 329, 457-468.

56. Zeng, P., Guo, Z., Xiao, X., Peng, C., Liu, L., Yan, D., He, Y., 2020. Physiological stress responses, mineral element uptake and phytoremediation potential of Morus alba L. in cadmium-contaminated soil. Ecotox. Environ. Safe. 189, 109973.

57. Zhang, F.-Q., Wang, Y.-S., Lou, Z.-P., Dong, J.-D., 2007. Effect of heavy metal stress on antioxidative enzymes and lipid peroxidation in leaves and roots of two mangrove plant seedlings (Kandelia candel and Bruguiera gymnorrhiza). Chemosphere 67, 44-50.

58. Zhang, H., Jiang, Y., He, Z., Ma, M., 2005. Cadmium accumulation and oxidative burst in garlic (Allium sativum). J. Plant Physiol. 162, 977-984.

59. Zhang, Z., Rengel, Z., Meney, K., Pantelic, L., Tomanovic, R., 2011. Polynuclear aromatic hydrocarbons (PAHs) mediate cadmium toxicity to an emergent wetland species. J. Hazard. Mater. 189, 119-126.

60. Zhao, Z.-Q., Zhu, Y.-G., Li, H.-Y., Smith, S.E., Smith, F.A., 2004. Effects of forms and rates of potassium fertilizers on cadmium uptake by two cultivars of spring wheat (Triticum aestivum, L.). Environ. Int. 29, 973-978.

61. Zhou, L., Xia, M., Wang, L., Mao, H., 2016. Toxic effect of perfluorooctanoic acid (PFOA) on germination and seedling growth of wheat (Triticum aestivum L.). Chemosphere 159, 420-425.

\section{Figures}



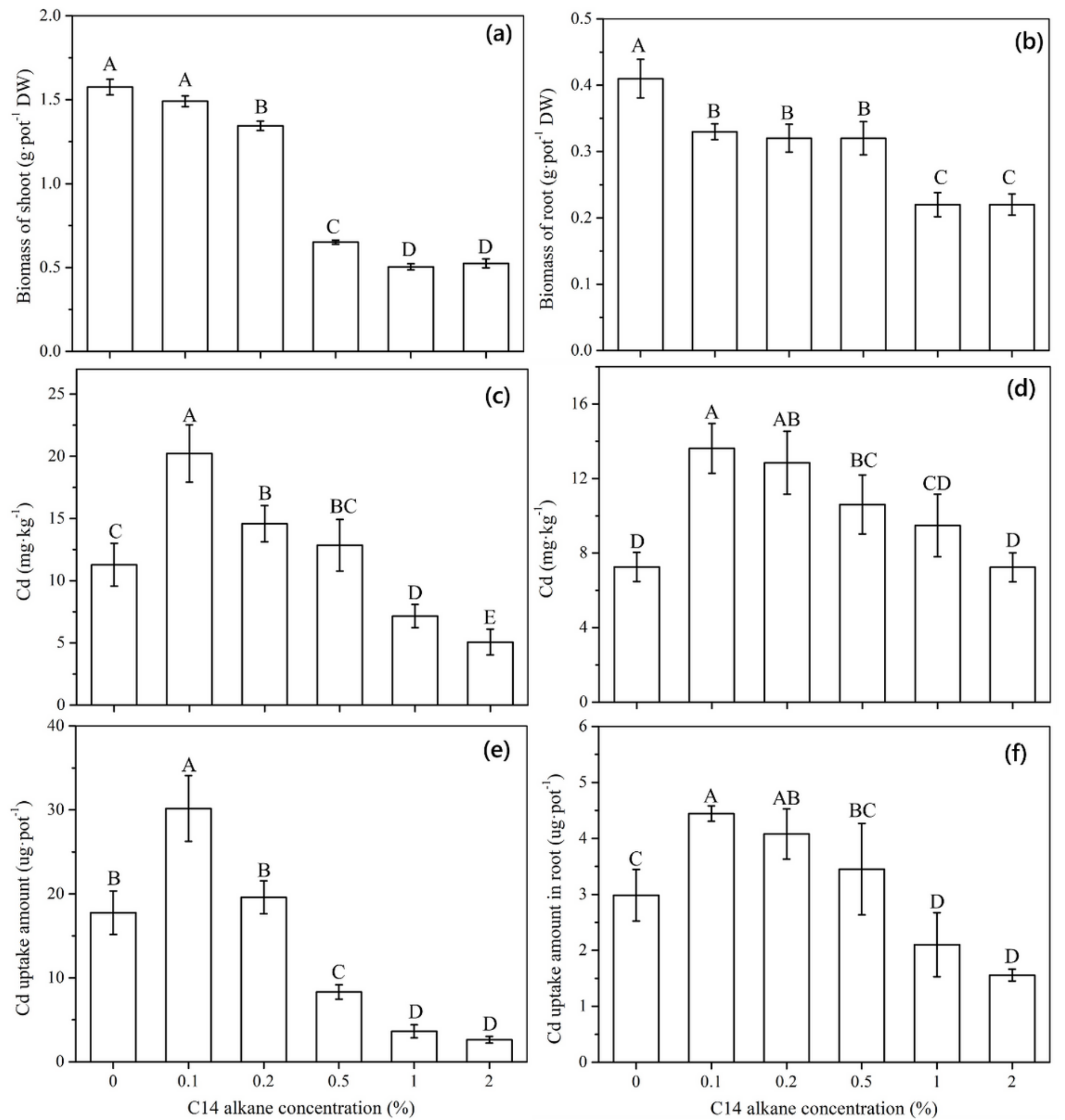

Figure 1

Effect of $\mathrm{C} 14$ alkane on the biomass, Cd concentration and uptake of ryegrass, (a) biomass of shoot, (b) biomass of root, (c) Cd concentration in shoot, (d) Cd concentration in root, (e) Cd uptake amount in shoot, (f) Cd uptake amount in root. Each value represents the mean \pm standard deviation of three independent experiments. Different uppercase letters on the column represented significant difference in different treatments of $\mathrm{C} 14$ alkane concentration $(\mathrm{P}<0.05)$. 

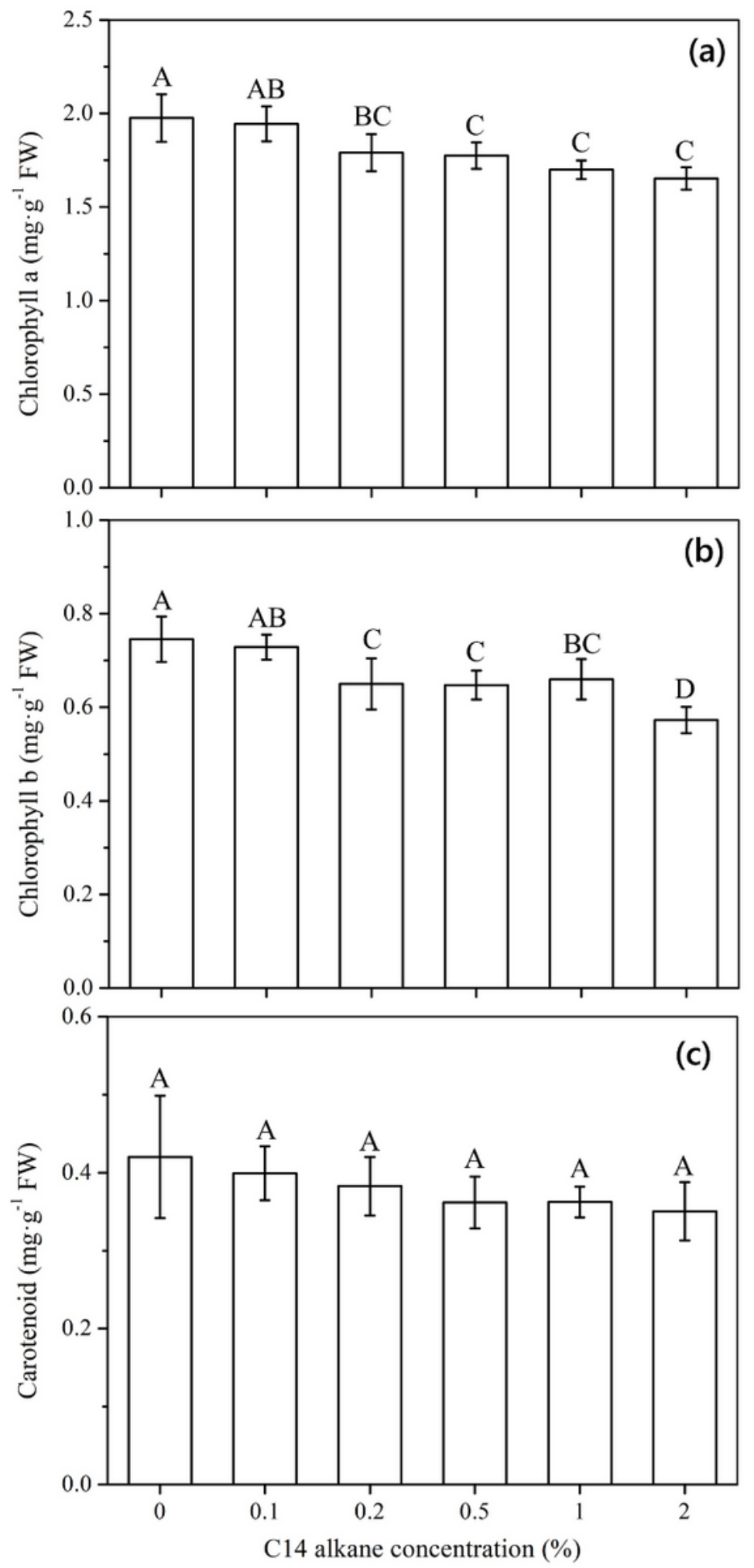

Figure 2

Effect of $\mathrm{C} 14$ alkane on the chlorophyll a, chlorophyll b, and carotenoid concentrations in leaves of ryegrass, (a) chlorophyll a, (b) chlorophyll b, (c) carotenoid concentrations. Each value represents the mean \pm standard deviation of three independent experiments. Different uppercase letters on the column represented significant difference in different treatments of C14 alkane concentration $(P<0.05)$. 

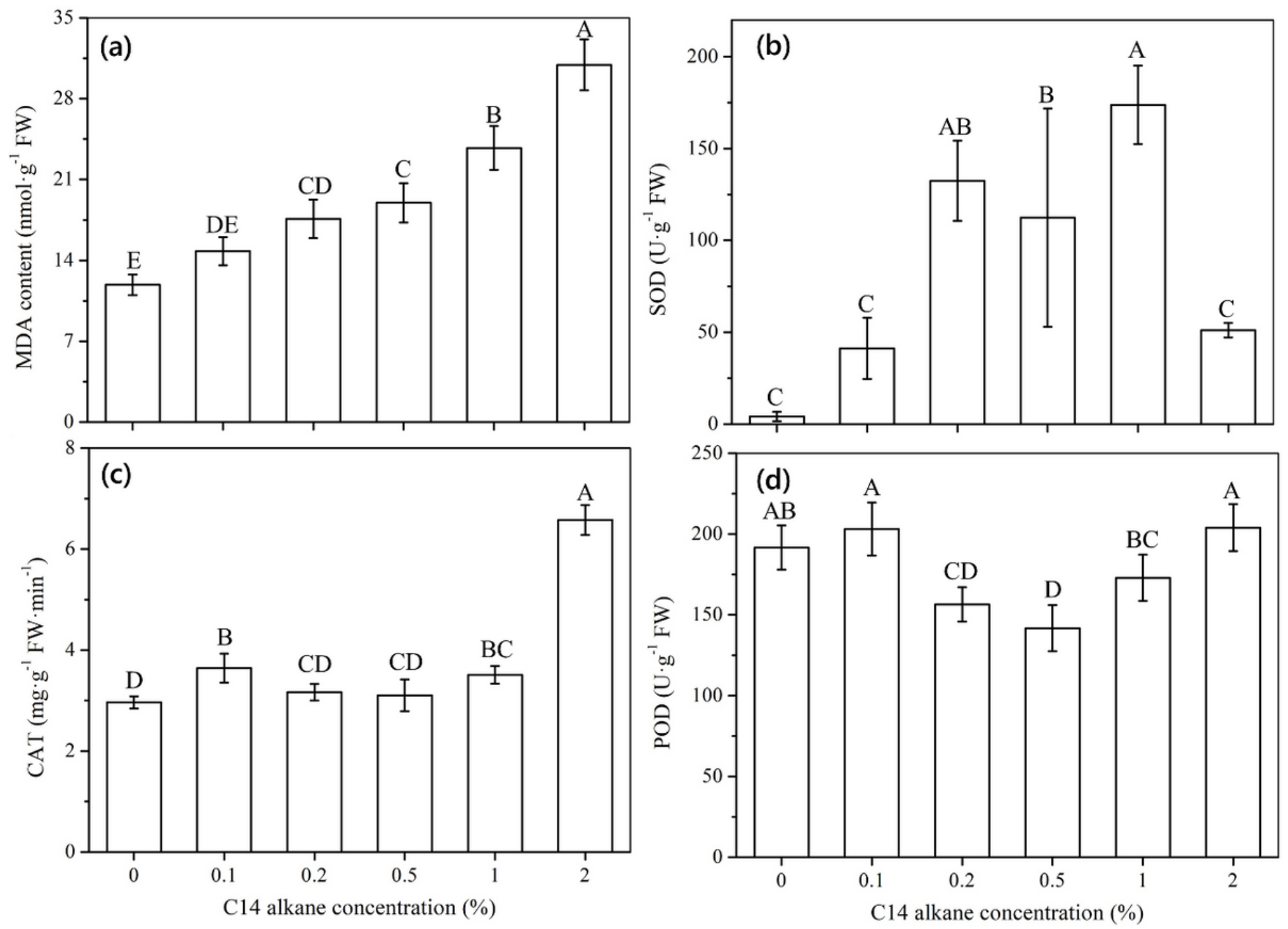

Figure 3

Effects of C14 alkane on membrane lipid peroxidation and the antioxidant enzyme activity in leaves of ryegrass. (a) MDA content, (b) SOD activity, (c) CAT activity (d) POD activity. Each value represents the mean \pm standard deviation of three independent experiments. Different uppercase letters on the column represented significant difference in different treatments of C14 alkane concentration $(P<0.05)$. 

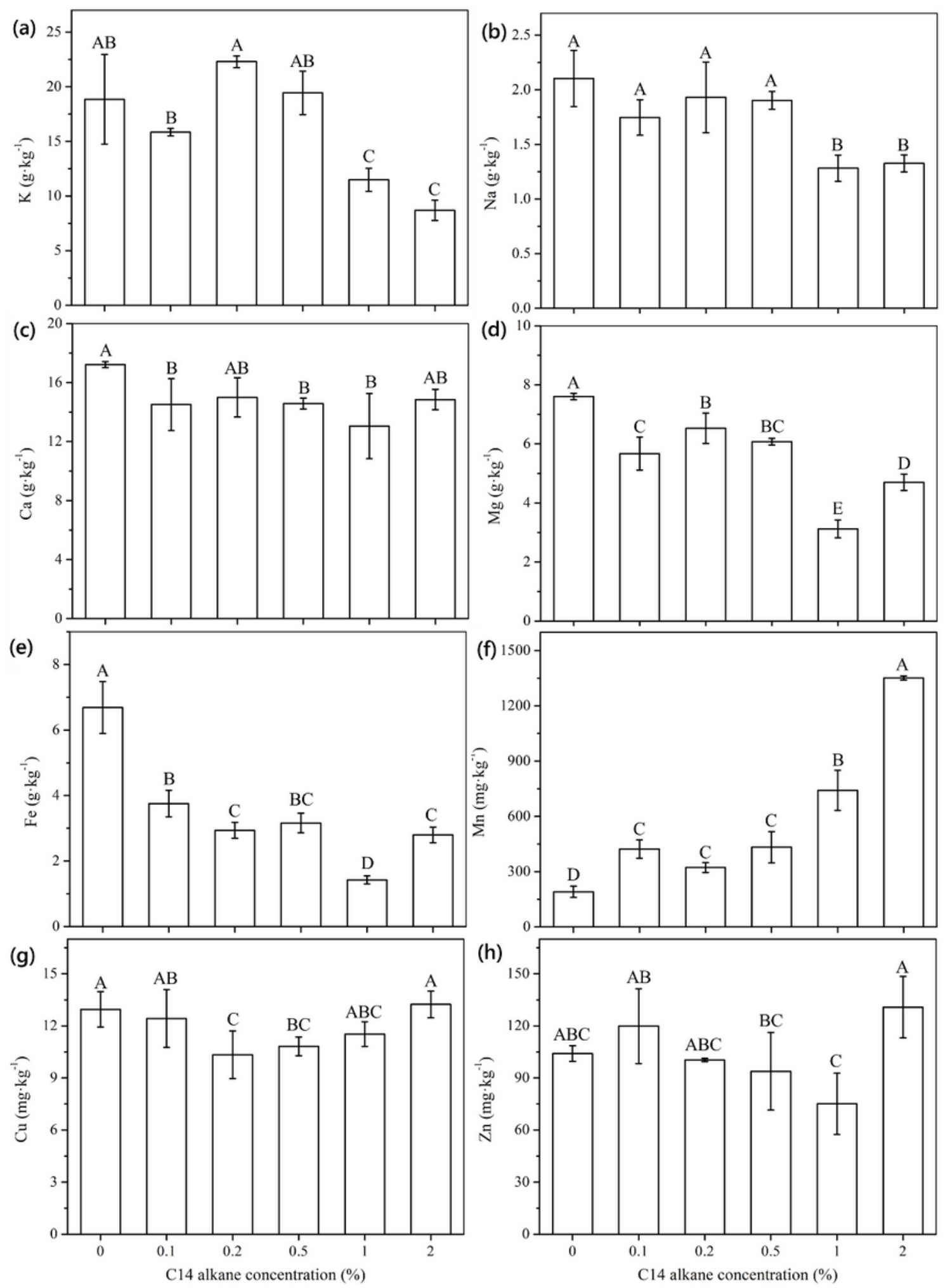

\section{Figure 4}

Effects of $\mathrm{C} 14$ alkane on mineral nutrient elements ( $\mathrm{K}, \mathrm{Na}, \mathrm{Ca}, \mathrm{Mg}, \mathrm{Fe}, \mathrm{Mn}, \mathrm{Cu}$, and $\mathrm{Zn}$ ) in shoots of ryegrass. (a) K content in shoot, (b) Na content in shoot, (c) Ca content in shoot, (d) Mg content in shoot, (e) Fe content in shoot, (f) Mn content in shoot, (g) Cu content in shoot, (h) Zn content in shoot. Each value represents the mean \pm standard deviation of three independent experiments. Different uppercase 
letters on the column represented significant difference in different treatments of $\mathrm{C} 14$ alkane concentration $(P<0.05)$.

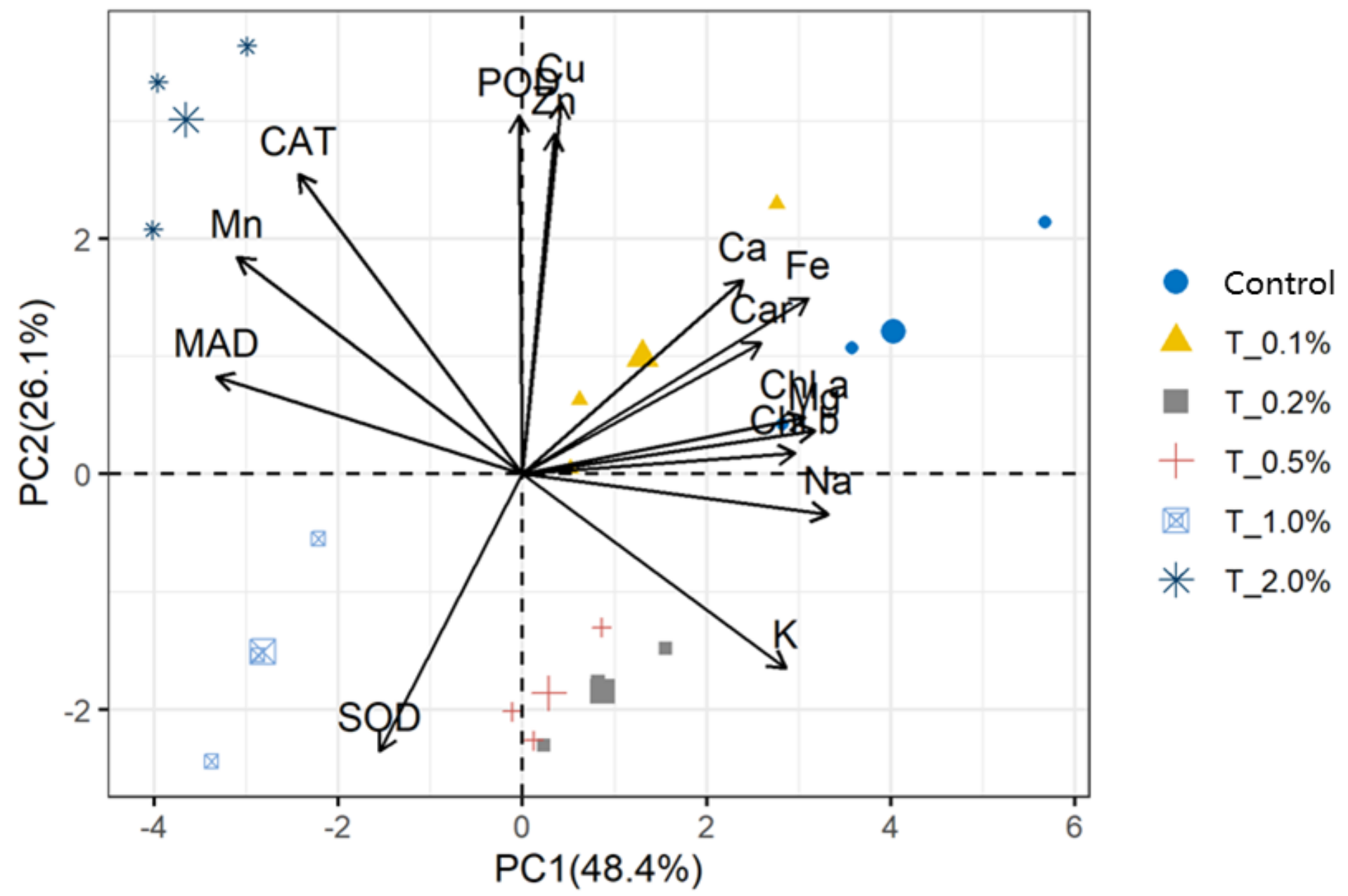

Figure 5

Principal component analysis (PCA) of chlorophyll content, antioxidant enzyme activities and mineral nutrient elements. Chl.a, Chl.b and Car were chlorophyll a, chlorophyll b and carotenoids contents of leaves, respectively. 

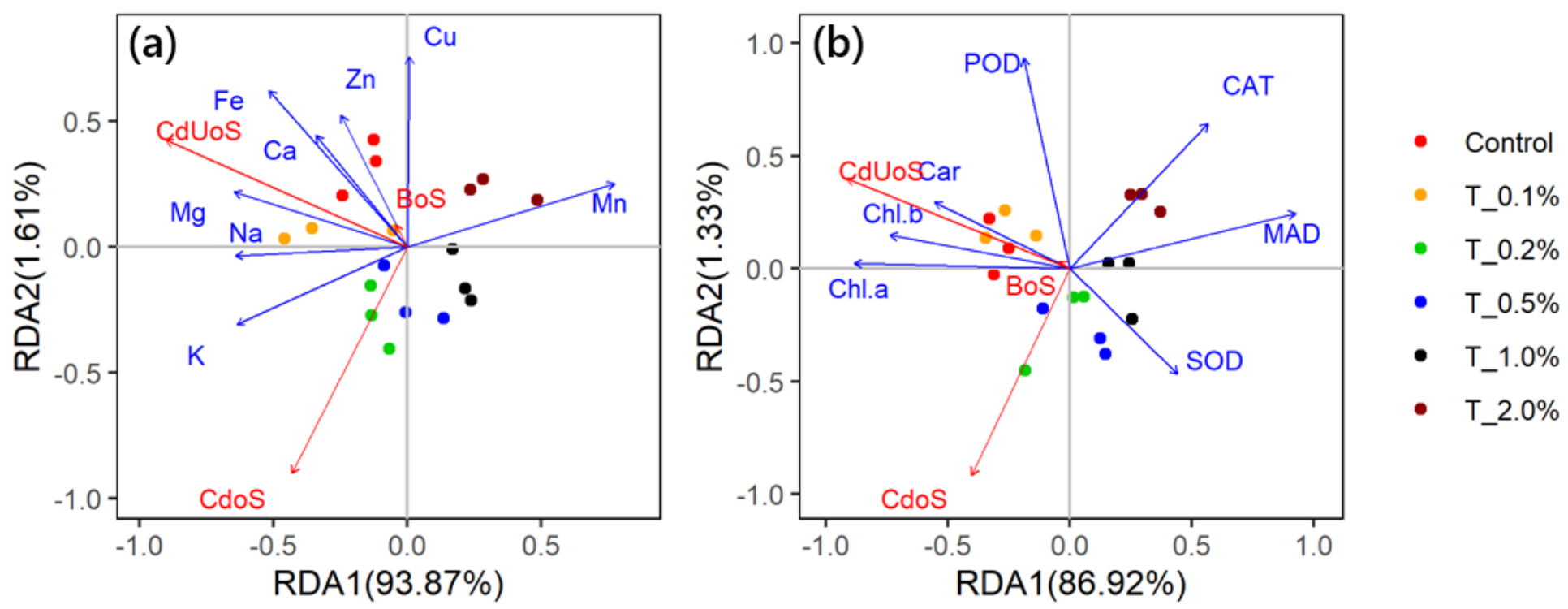

Figure 6

RDA of $\mathrm{Cd}$ accumulation indices (biomass, $\mathrm{Cd}$ content and $\mathrm{Cd}$ uptake amount) composition with respect to (a) chlorophyll content, antioxidant enzyme activities and (b) mineral nutrient elements in shoot of ryegrass. Chl.a, Chl.b and Car were chlorophyll a, chlorophyll b and carotenoids contents of leaves, respectively. Bos, CdoS and CdUoS were biomass, Cd content and Cd uptake amount, respectively.

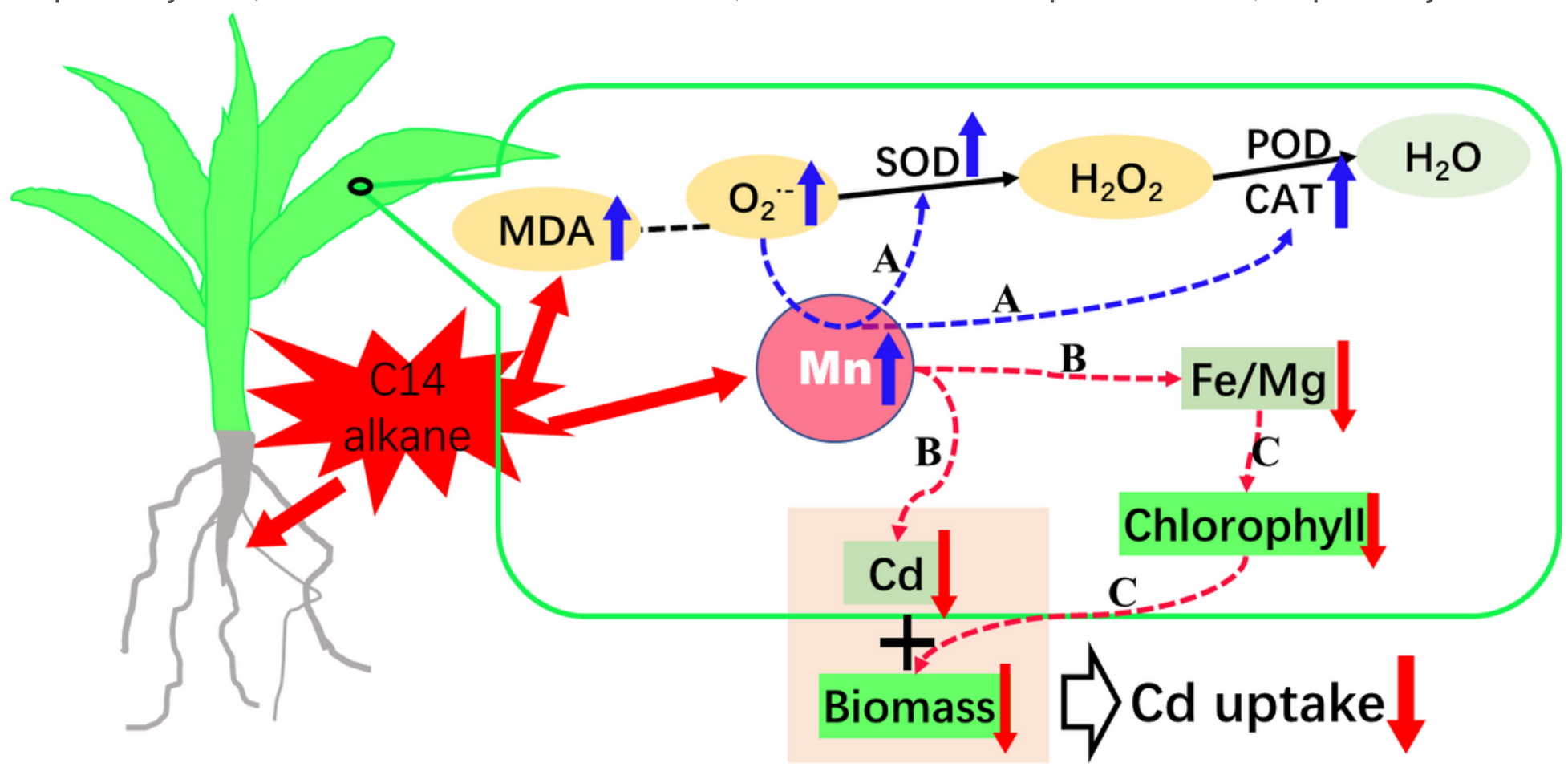

Figure 7

The influence mechanism of C14 alkane stress on Cd uptake of ryegrass. A: The increase of $\mathrm{Mn}$ induced by $\mathrm{C} 14$ alkane increased SOD and CAT to reduce C14 alkane toxicity to ryegrass. B: The competitive 
uptake with $\mathrm{Mn}$ decreased the $\mathrm{Cd}, \mathrm{Fe}$ and $\mathrm{Mg}$ content; C: The decrease of $\mathrm{Mg}$ and Fe decreased of chlorophyll content and inhibited the growth.

\section{Supplementary Files}

This is a list of supplementary files associated with this preprint. Click to download.

- Supportinginformation.docx 